\title{
New Australian species and typifications in Veronica sens. lat. (Plantaginaceae)
}

\author{
Barbara G. Briggs ${ }^{1}$ and Friedrich Ehrendorfer ${ }^{2}$ \\ ${ }^{1}$ Botanic Gardens Trust Sydney, Mrs Macquaries Road, Sydney NSW 2000, Australia. \\ Email:barbara.briggs@rbgsyd.nsw.gov.au \\ ${ }^{2}$ Institute of Botany, University of Vienna, Rennweg 14, A-1030, Vienna, Austria. \\ Email: friedrich.ehrendorfer@univie.ac.at
}

\begin{abstract}
Four Australian species of Veronica sens. lat. are newly described and illustrated; lectotypes are selected for other species and synonyms. In V. 'sect. Derwentia' (Raf.) B.G.Briggs (in Garnock-Jones et al. submitted) we informally recognise three clades: the Derwentia clade, the $V$. formosa clade and the $V$. calycina clade. A second species of the $V$. formosa clade, V. continua, is newly described; both $V$. continua and $V$. formosa being Tasmanian endemics. New Australian mainland taxa of the V. calycina clade are V. grosseserrata, V. sobolifera and V. subtilis; types and synonyms are listed for V. brownii, V. calycina, V. distans, V. gracilis, V. hillebrandii, V. notabilis, V. novae-hollandiae, V.parnkalliana and V.plebeia. From V. sect. Hebe, typification and synonyms are provided for $V$. densifolia.
\end{abstract}

\section{Introduction}

Veronica and related genera of the Veroniceae were, until recently, regarded as members of the Scrophulariaceae. The results of DNA analyses have, however, led to drastic changes in the circumscription of the family and the reclassification of Veronica as a member of the Plantaginaceae (Olmstead \& Reeves 1995, Olmstead et al. 2001, Albach et al. 2005). Such analyses have also made clear that Veronica is paraphyletic if Southern Hemisphere genera such as Derwentia, Parahebe, Hebe and Chionohebe are recognised (Albach \& Chase 2001, Wagstaff et al.2002). A greatly enlarged genus Veronica is therefore now accepted by Albach et al. (2004), Garnock-Jones et al. (submitted) and Albach et al. (submitted), although Bayly and Kellow (2006), in their comprehensive account of Hebe and Leonohebe, continue to recognise these at generic level 'as segregates of the larger, mostly northern hemisphere genus Veronica' and Brummitt (2006) regards a satisfactory classification of Veronica as incompatible with the recognition of only monophyletic taxa. The main consequences of an expanded Veronica for species native in Australia are the inclusion of all the Southern Hemisphere clades of Veronica in one subgenus that includes three sections: 'sect. Detzneria (Schltr. ex Diels) Albach' (in Garnock-Jones et al. submitted), 'sect. Derwentia (Raf.) B.G.Briggs' (in Garnock-Jones 
et al. submitted; both sectional names to be formally published in that paper and a choice to be made there between the competing subgeneric names), and sect. Hebe (Juss.) G.Don.

The first of these sections includes only' $V$.(= Detzneria) tubata (Diels) Albach' (GarnockJones et al. submitted) in New Guinea. The second section, ' $V$. sect. Derwentia', consists of

(1) all the somewhat woody Australian taxa treated under Derwentia by Briggs and Ehrendorfer (1992) together with Parahebe lithophila B.G.Briggs \& Ehrend., here informally referred to as the Derwentia clade,

(2) the relatively isolated Veronica formosa clade with two species from Tasmania, and also

(3) a number of herbaceous and predominantly Australian taxa listed under Veronica sect. Chamaedrys, group Calycina by Römpp (1928).

The latter taxa, treated as the V. calycina clade in the present study, are represented in the analyses of DNA data (Wagstaff \& Garnock-Jones 1998, 2000; Wagstaff et al. 2002 ) by two species reported as V. calycina and V. arguta (a synonym of V. brownii), and these changes clearly support their placement within ' $V$. sect. Derwentia'. Indeed, the phylogeny presented by Wagstaff et al. (2002) suggests that the calycina clade is embedded in the Derwentia clade. With respect to their morphology, the taxa of the $V$. calycina clade correspond with Northern Hemisphere Veronica sens. strict. (particularly $V$. sect. Chamaedrys, $x=8$ ). They are polyploids with $2 n=36$ (rarely $2 n=34$ ) and $2 n$ $=72$ and thus exhibit a secondary base number of $x=18$ (rarely 17) in contrast to all other members of the 'Hebe complex' of Veronica (Heads 1992, Bayly \& Kellow 2006, and other authors) which have secondary base numbers of $x=21,20$ and 19 (Briggs \& Ehrendorfer 2006).

Together with Albach et al. (submitted), we interpret all these secondary base numbers as derived from hexaploid ancestors and descending dysploidy. A hexaploid number of $2 n=48$ was reported (Borgmann 1964) in the monospecific New Guinean ' $V$. sect. Detzneria' but our studies (Briggs \& Ehrendorfer 2006), although giving only a very approximate count, show $2 n=38-42$. There may have been hexaploidy from a primary base number of $x=8$ (as in $V$. sect. Chamaedrys) or hexaploidy may have followed dysploid change to $x=7$. The closely related $V$. sect. Hebe (with $x=21$ and 20) includes the former genera Hebe, Heliohebe, Leonohebe, Chionohebe and most of Parahebe and has its greatest species diversity in New Zealand but extends to New Guinea, French Polynesia and South America; it is represented on the Australian mainland only by $V$. densifolia and in Tasmania by the species that has been known as Chionohebe ciliolata (Hook.f.) B.G.Briggs \& Ehrend. Bayly and Kellow (2006) observe that in sect. Hebe 'it seems likely that independent origins of polyploidy have been relatively common', given that polyploidy is found in taxa with both $x=20$ and 21 chromosomes, morphologically divergent taxa with the same base chromosome number, and within at least some species'.

In accordance with the new phylogenetic concept of Veronica sens. lat., we provide descriptions and illustrations for four new Australian species. With respect to ' $V$. sect. Derwentia', including the clades of V. calycina and V. formosa, lectotypes are selected for four species and the types of seven other species are listed. Types are also indicated for synonyms of the species now recognised, and one of these is lectotypified. Citations 
of the types of the species classified under Derwentia and Parahebe by Briggs and Ehrendorfer (1992) are not repeated here. Of the two species that have been included in Chionohebe (now in V. sect. Hebe) and that are common to Australia and New Zealand, V. densifolia is lectotypified here, but the other is discussed by Garnock-Jones et al. (submitted). With respect to $V$. subgenus Beccabunga subsect. Serpyllifolia, it is probable that the occurrences of V. serpyllifolia L. sens. lat. in Australia are partly native to this country and partly naturalised introductions (Briggs \& Barker 1999); they are not included in this study.

\section{'Veronica sect. Derwentia': V. formosa clade}

Veronica formosa, a somewhat woody species from Tasmania, was discussed in our study of the Australian representatives of Derwentia and Parahebe (Briggs \& Ehrendorfer 1992). It shows $2 n=42, x=21$, but was provisionally left in Veronica as of uncertain position. DNA data available now (Wagstaff et al. 2002: listed as Hebe formosa) clearly demonstrate that it is a basal and relatively isolated member of ' $V$. sect. Derwentia', a group that links the Northern with the Southern Hemisphere clades of the genus. We now provide a description and illustration of a second species of the clade, V. continua, and lectotypification of $V$. formosa.

Veronica continua B.G.Briggs, sp. nov.

A Veronica formosa combinatione characterum sequentium distinguitur: caules vix ramificantes; folia majora, (12-)15-30(-35) mm longa, (3.5-)5-9(-11) mm lata, oblonga vel lanceolata; racemi non nisi ad nodos supremos; racemi longiores, racemi fructiferi (2-)4-10 cm longi, flores 15-30 gerentes; capsulae majores, 5-7.5 mm longae, 6-9 mm latae.

Holotype: Tasmania: $2.4 \mathrm{~km}$ NW of Cranbrook Rd, on road to Hardings Falls, W of Bicheno (41 52' S 148 02’ E), B.G. Briggs 9149, 24 Jan 1993 (HO). Isotypes NSW, CANB, MEL.

Erect woody herb to $1.5 \mathrm{~m}$ tall. Stems $1-8$ per plant, with few branchings, continuing growth (usually without branching) after flowering for several seasons before falling and being replaced by new shoots from the perennial base, terete, the longest internodes 0.4-1.2 cm long, 1.5-3.5 mm diam., hirsute with spreading hairs in a longitudinal band below the leaf sinus; hairs $0.3-1.3 \mathrm{~mm}$ long, of 3-6 cells; surface of the old stems clothed in old flaking leaf bases. Leaves opposite, decussate, entire, sessile, stem-clasping, firm textured, smooth, oblong to lanceolate, spreading or strongly reflexed, (12-)15-30(-35) $\mathrm{mm}$ long, (3.5-)5-9(-11) mm broad, glabrous except for rigid white cilia on margin towards the base, acute, apex often recurved, midvein deeply impressed above and prominent below, secondary venation discernable on abaxial surface; base of young leaf fused with the opposite leaf base but splitting apart with age. Racemes arising in the uppermost axils of the season's growth or a few on a short bracteose lateral branch in an upper axil, (2-)4-10 cm long, most of the length floriferous; with 15-30 flowers. Flowers in the axils of linear bracts that are (3-)5-8(-9.5) $\mathrm{mm}$ long. Fruiting pedicels 4-9 mm long. Calyx lobes narrow triangular, acuminate, 3.5-4.7 mm long and 1-1.5 $\mathrm{mm}$ broad in fruit, with short hairs on margin. Corolla blue, 8-9.5 mm long; adaxial lobe broad ovate, obtuse, 6-9.5 mm long, 5-7.6 mm broad; abaxial lobe obtuse, ovate but narrower than the adaxial lobe, 5.5-9.5 mm long, 3-6 $\mathrm{mm}$ broad; lateral lobes elliptical to obovate, not folded, c. $6 \mathrm{~mm}$ long, 3.5-4.5 mm broad; the tube very short and broad, glabrous. Stamens: filaments 3.5-5.5 mm long; anthers 1.8-3.2 mm long. 


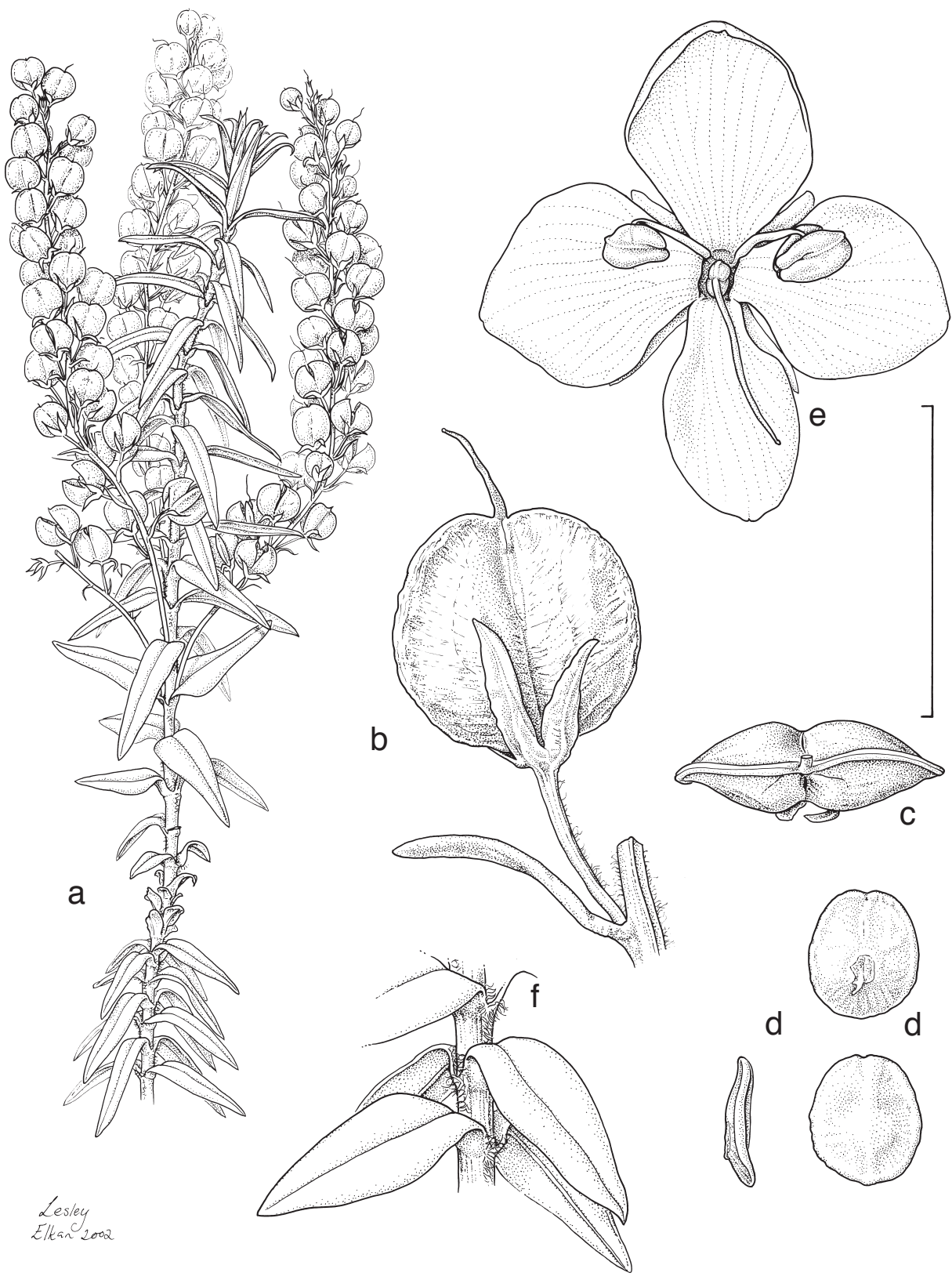

Fig. 1. Veronica continua. a, leafy branch with fruiting racemes; b, capsule, lateral view; c, capsule, apical view; $\mathbf{d}$, seed, adaxial, abaxial and lateral views; e, flower; $\mathbf{f}$, leaf and stem detail (a-d, f from type collection; e from Collier 3793). Scale bar: $\mathrm{a}=5 \mathrm{~cm} ; \mathrm{b}, \mathrm{c}=0.75 \mathrm{~cm} ; \mathrm{d}=0.6 \mathrm{~cm}$; $\mathrm{e}=1 \mathrm{~cm} ; \mathrm{f}=2 \mathrm{~cm}$. 
Capsule strongly flattened, with a narrow septum, glossy, glabrous, broad ovate, 5-7.5 $\mathrm{mm}$ long, 6-9 mm broad, apex slightly emarginate to truncate; dehiscing by a septicidal split, initially $1 / 4$ to $1 / 3$ to the base, eventually splitting to base; style \pm persistent, 4.5-5.5 mm long, glabrous. Seeds to 12 in number, almost circular in outline, thin, smooth, flat or slightly concavo-convex, 2-2.5 mm long, 1.6-2.4 mm broad. (Fig. 1).

Distinguished from $V$. formosa, which is widely distributed in the eastern half of Tasmania, by the stems less branched; leaves larger, lanceolate to narrow elliptic, often strongly reflexed (less often spreading); racemes developed only at the uppermost nodes of the current season's growth; racemes longer with more flowers; larger capsules. In $V$. formosa the leaves are (5-)10-18(-21) mm long and (2-)3-5(-7) mm wide, ovate to narrow elliptic, spreading or less often recurved; racemes are mostly on short lateral branches developed at most of the nodes of a previous season's growth; racemes (0.2-)0.5-3 cm long with 2-12(-18) flowers; capsules 3.5-6 mm long, 3.5-5.5 mm broad. Occasional departures from the normal mery have been noted in V. continua, with a small proportion of 3- and 4- locular capsules and rarely one of the lateral corolla lobes divided into two. Veronica continua shows many similarities to the more variable $V$. formosa which has a more shrubby and compact form, well adapted to the less sheltered habitats of mountain areas in Tasmania where it commonly occurs. Altogether, the small $V$. formosa clade in its morphology and karyology is clearly related to the Australian taxa formerly included in Derwentia (Briggs \& Ehrendorfer 1992).

The epithet is from the Latin continuus = continuous, unbroken; referring to the stems continuing growth after flowering for several seasons with little or no branching.

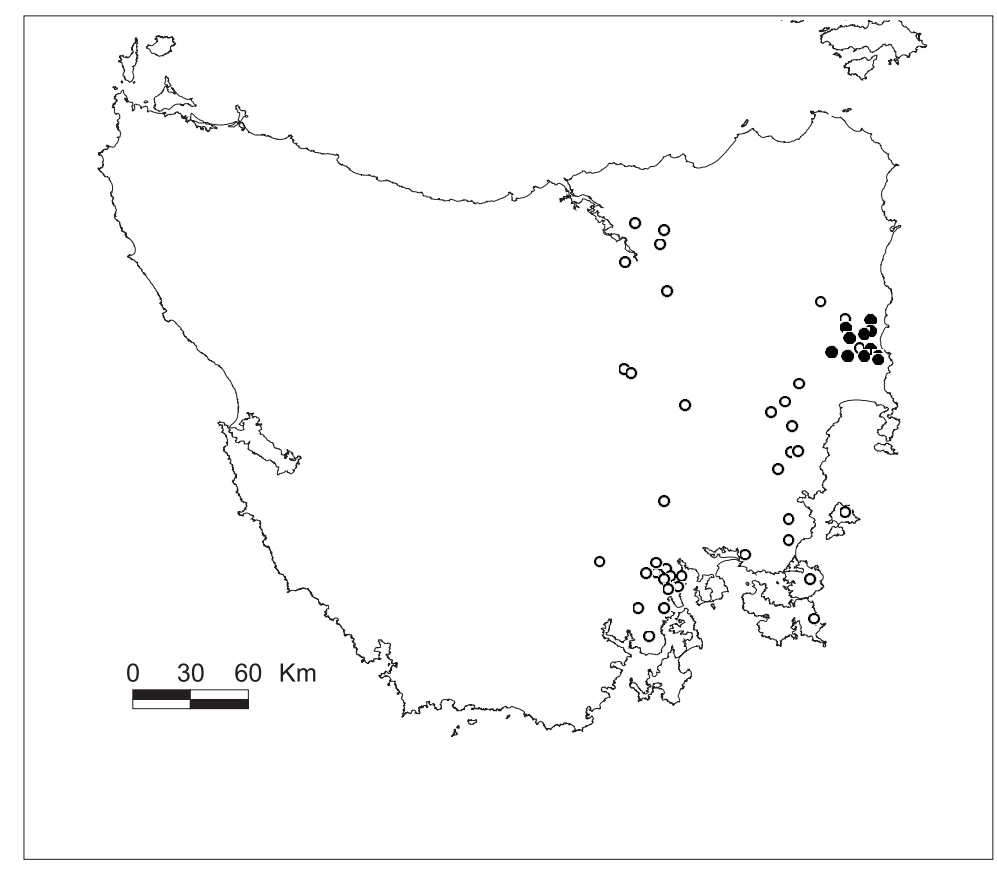

Fig. 2. Distribution of V. continua $\bullet$ and $V$. formosa $\odot$ in Tasmania. 
Distribution: towards the north-east of Tasmania, growing on rocky hillsides, pebbly ground in a riverine flood zone, cliff ledges; sometimes in wet sclerophyll forest, mostly on dolerite (Fig. 2).

Conservation status: restricted in distribution, occurring in an area managed as native forest and perhaps not currently endangered. Veronica continua is found in rocky areas, or sites with sparse undergrowth, suggesting that the species is confined to sites with some protection from wildfires. Its present region of occurrence was a refugium during colder and drier glacial times (Coates et al. 1999; Kirkpatrick \& Brown 1984a). The region includes a considerable number of endemic Tasmanian species, especially in fire-protected sites such as cliff faces, rocky gorges and alpine plateaus (Kirkpatrick \& Brown 1984b). This handsome species has, for more than two decades, been in cultivation and marketed by plant nurseries specialising in species native to Tasmania.

Selected specimens examined: Tasmania: East Coast: Marshes Hd of Douglas River, Milligan, 12 Dec 1851 (K); Coal Marsh near Apsley River, Collier 3793, 13 Nov 1988 (HO); Nichols Cap, W of Seymour Beach, Harris, 25 Jan 1979 (HO); Organ Hill near Bicheno, Moscal 192, 20 Mar 1980 (HO); Blindburn Creek, NW of Bicheno, Gray 600, 9 May 1982 (HO); Hardings Falls, Swan River, WNW of Bicheno, Briggs 9148, 24 Jan 1993 (NSW); Apsley River, Collier 922, 2 Nov 1985 (HO); Lilla Villa Bridge, SW of Bicheno, Simmons, 20 May 1982 (HO); Lilla Villa Bridge, Apsley River, Buchanan 222, 23 Jan 1980 (HO); Apsley River, by main road bridge, S of Bicheno, Gordon, 19 Nov 1942 (HO).

Veronica formosa R.Br., Prodr. 434 (1810).

= Hebe formosa (R.Br.) Cockayne, Trans. \& Proc. New Zealand Inst. 60: 470 (1929).

三 Parahebe formosa (R.Br.) Heads, Bot. J. Linn. Soc. 115: 69 (1994).

=Derwentia formosa (R.Br.) Bayly in Bayly \& Kellow, Illustrated Guide to New Zealand Hebes. 328 (2006).

Lectotype (here designated): [Tasmania] Ad rupes saxosas fluvii Cataract R., in Porta Dalrymple [near Georgetown], R. Brown, 10 Jan 1804 (BM!, marked 'A' on the sheet, photo NSW). Probable isolectotypes: MEL 21612!, 21613! and NSW 6234!, which are in similar fruiting condition but lack locality notes. Residual syntypes: 'In montibus prope fluv. Derwent. In collibus supra Sullivan Cove. In monte Tabulari' [Mt Wellington], R. Brown, 27 Feb. 1804 (BM!, photo NSW, isosyntype K!). The residual syntypes in BM are mounted on the same sheet as the lectotype; of the five pieces on the sheet, only piece 'A' can be readily matched to a locality.

\section{'Veronica sect. Derwentia': V. calycina clade}

As presently known, the Veronica calycina clade is made up of 12 perennial, herbaceous Australian species of which one (V.plebeia) also occurs in New Zealand, where its native or naturalised status is unclear (Sykes 1988). There is considerable polymorphism, associated with the polyploid and reticulate nature of the clade. Chromosome numbers are all polyploid, mostly on the secondary and reduced hexaploid base number $x=$ $18,(2 n=36$ or 72$)$, only $V$. plebeia appears further reduced to $2 n=34$, i.e. $x=17$ (Briggs \& Ehrendorfer 2006). No comprehensive survey of the clade is yet available, but treatments in the floras of South Australia (Barker 1986), New South Wales (Briggs et al. 1992) and Victoria (Briggs \& Barker 1999) supply partial information, including brief descriptions and keys for the identification of the new taxa described here. Three 
new species, V. grosseserrata, $V$. sobolifera and $V$. subtilis, are described and illustrated below. We also provide notes on the typification of the other nine species recognised within the $V$. calycina clade and their synonyms.

Veronica grosseserrata B.G.Briggs \& Ehrend., sp. nov.

A Veronica notabilis combinatione characterum sequentium distinguitur: pili indumentorum rigentiores; laminae foliorum ad basim truncatae, grosse serratae; lobi calycis acutiores, densius ciliati; capsulae truncatae, apicem versus latae.

Holotype: New South Wales: Mt Boss (lower slope), $43 \mathrm{~km} \mathrm{NW}$ of Wauchope. (Mt Boss State Forest at Camerons Forest Camp), alt. 1096 m., R.G. Coveny, P.D. Hind \& R. Hancock, 15 Feb 1975 (NSW). Isotypes BRI, CANB, K, MEL, NY.

Herbs with procumbent stems and ascending to erect flowering stems, the procumbent stems commonly becoming ascending to erect distally, or sometimes the flowering stems becoming procumbent and continuing vegetative growth into the next season. Flowering stems (8-)12-30(-45) cm long; longest internodes $2-7(-9) \mathrm{cm}$; stem hairs mostly short, $0.2-1 \mathrm{~mm}$ long, stiff, yellowish, scattered, multicellular, to 8 cells long, the cell walls mostly not collapsed when dry, antrorsely curved, very rarely with glandular heads. Leaves: petioles 5-12(-17) $\mathrm{mm}$; laminae angular-ovate to almost triangular, broadest towards base, 30-55(-90) mm long, (9-)11-20(-35) mm broad, base broadly cuneate or truncate, apex acute, margins grossly serrate with 6-12 apiculate, uneven, spreading teeth on each side, the largest teeth toward the base, texture thin, green to dark brown or somewhat blackish when dry, \pm palmately nerved with 5-7 nerves from near the base and 2-3 major nerves higher up on each side of the midvein, the margin slightly revolute and scarcely thickened, with short curved hairs on the upper surface and on the veins of the lower surface and the margin, but the lower surface glabrous or with sparse hairs between the veins. Racemes single or mostly paired at 2-4 nodes on the upper $1 / 2$ of the stem but sometimes \pm irregularly distributed, (45-)60-140(-160) $\mathrm{mm}$ long, with (6-)10-16(-20) flowers; peduncle (10-)15-40(-60) mm long. Bracts narrow-obovate, 4-6 mm long. Fruiting pedicels 6-13 mm long. Calyx lobes obovate, acute to obtuse, almost doubled in size from flower to fruit, finally $5-8 \mathrm{~mm}$ long, $1.5-3.5$ $\mathrm{mm}$ broad, with short curved hairs on the margins (including the apex) and scattered on the outer surface and veins. Corolla at first white, becoming mauve, 3-6(-8) $\mathrm{mm}$ long; lobes obovate to very broad obovate, not folded. Capsule glabrous or with a few short hairs on and near upper margins, somewhat glossy, slightly emarginate, 4-5 mm long, breadth slightly greater than length; style \pm equal to fruit length. Seeds broadly ovoid, flattened, very slightly rugulose and somewhat glossy, light brown, 1-1.5 mm long. (Fig. 3, a-c).

Veronica grosseserrata is octoploid $(2 n=72)$ (Briggs \& Ehrendorfer 2006). It can be distinguished from $V$. notabilis F.Muell. ex Benth. (tetraploid, $2 n=36$ ) by its indumentum of more rigid hairs, with the cells not collapsed when dry; more truncate and more deeply serrate leaves with sparser hairs on lower surface; more strongly ciliolate calyx lobes; capsules that are more truncate and broader toward the apex. Despite the reported difference in ploidy level, some collections suggest that there is hybridisation between the two taxa. Veronica grosseserrata was referred to as 'Veronica sp. C' in Briggs et al. (1992, p. 580), and as 'Veronica sp. 1' in Briggs and Barker (1999, p. 515). 
The epithet is from the Latin and refers to the deep serration of the leaves.

Distribution: South-eastern Queensland, North and Central Coast and Tablelands of New South Wales, and in the eastern half of Victoria. In moist eucalypt forest and openings in rainforest. (Fig. 4).

Conservation status: widespread and common.

Selected specimens examined: Queensland: Mt Merino, McPherson Range, Blake 15371, 9 Dec 1943 (BRI); Wilsons Peak, Forster 15702 \& Leiper, 21 Aug 1994 (BRI). New South Wales: North Coast:Clarence River, [Beckler] (MEL 17933); Moonan Brook, Carter, 1884 (MEL 17935); Mt Boss State Forest, c. 15 miles [25 km] NW of Wauchope, Constable, 31 Oct 1956 (NSW 42216); Gloucester Tops, Coveny, 1 Jan 1967 (NSW 95319); c. 32 miles [50 km] SW of Gloucester, Coveny, 30 Nov 1967 (NSW 98194); Dorrigo, Heron, May 1912 (NSW 5966); Timbarra, New England, Stuart 682, (MEL); Mt Warning, White \& Brass, 1 Jan 1938 (K); Gibraltar Range, c. 42 miles [65 km] NE of Glen Innes, Williams, Feb 1961 (NE). Northern Tablelands: Mt Spirabo summit, E of Deepwater, Constable, May 1961 (NSW 57445); Point Lookout, New England National Park, Williams, 4 Jun 1967 (NSW 96612). Central Tablelands: Base of Scenic Railway, Katoomba, Ehrendorfer \& Briggs, 22 Oct 1966 (NSW 94525); Katoomba, Briggs, 26 Dec 1967 (NSW 101559); Blue Mountains, Bufton, 1893 (MEL 17937); Blue Mountains, Lamont 328, Mar 1888 (BM). Southern Tablelands: Wark's Road A.C.T., Gray, 21 Mar 1959 (CANB 168031); Sugarloaf Mountain, Gauba, 23 Feb 1951 (CANB); Humes River (MEL 17934). Victoria: Mountain Creek, near turn-off to Trapper's Gap, Tawonga district, Rodd 380, 27 Dec 1966 (NSW); Dividing Ranges, Walter, Nov 1898 (NSW 5985).

Veronica sobolifera B.G.Briggs \& Ehrend., sp. nov.

A Veronica gracilis combinatione characterum sequentium distinguitur: caules florentes longiores (plerumque 10-40 cm longi); folia majora latioraque, 13-30 mm longa, 8-15(-22) mm lata, dentibus 6-16; racemi flores 6-20 gerentes; lobi calycis majores latioresque.

Holotype: Gloucester Tops, New South Wales, R.G. Coveny, 1 Jan 1967 (NSW 98196). Isotypes BRI, K, MO.

Herbs with subterranean rhizomes and erect stems, without surface runners. Rhizomes extensively developed and with small scale-like leaves, finally bending upwards to produce erect flowering stems. Flowering stems (6-) $10-40 \mathrm{~cm}$ long, often with leafy lateral branches below the inflorescence; longest internodes (10-)15-60 mm long; stem hairs fine but rigid, mostly antrorsely curved, to $0.7-1 \mathrm{~mm}$ long, cells not collapsed when dry, hairs usually confined to lateral bands towards base of stems but scattered (often densely) over whole stem in upper parts. Petioles 1-2(-5) mm long. Leaf laminae broadly ovate, 13-30 mm long, 8-15(-22) mm broad; the base truncate; apex acute, margins serrate with 3-8 somewhat uneven, apiculate teeth on each side, the lower ones larger than the upper and spreading; texture relatively thick; greenish to blackish when dry; \pm palmately nerved with 3-5 nerves from near the base and 2-4 major nerves higher up on the midrib; upper surface glabrous except for very small papillose hairs towards the margin; lower surface with scattered antrorsely-curved hairs on and between the nerves. Racemes single or paired on 1-3 nodes of the upper $1 / 3-1 / 2$ of the stem, (30-)40-70(-130) mm long with 6-20 flowers; peduncle 15-35 mm long. Bracts broadly ovate, often rather large, to $8 \mathrm{~mm}$ long. Pedicels $8-20 \mathrm{~mm}$ long, ascending to erect, rather stiff. Calyx lobes elliptic to broad obovate, acute, almost doubled in size 


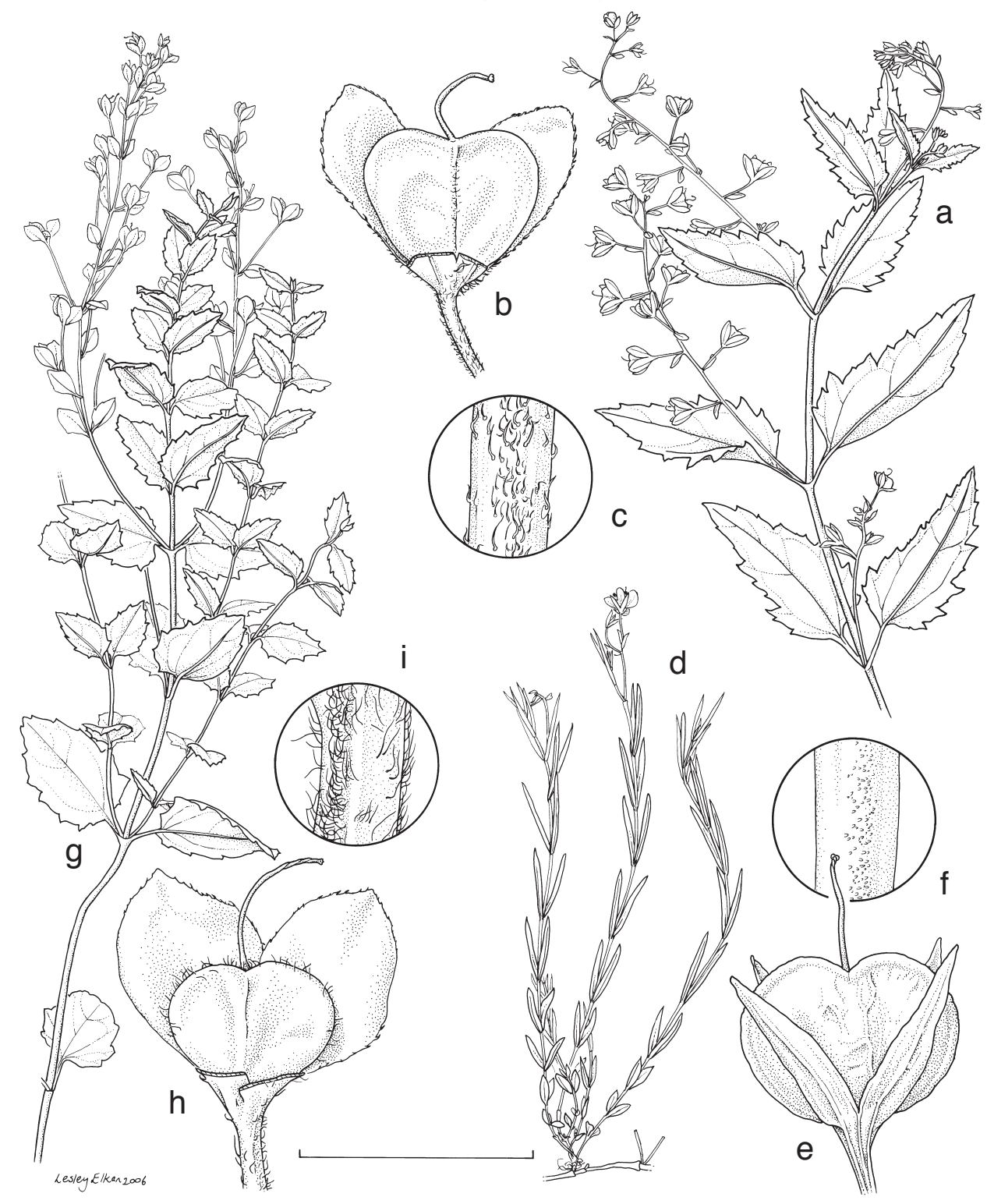

Fig. 3. a-c, Veronica grosseserrata. d-f, V. subtilis. g-i, V. sobolifera. a, d, g, leafy branches with flowering or fruiting racemes; $\mathbf{b}, \mathbf{e}, \mathbf{h}$, capsule with calyx (calyx partly removed in $\mathbf{b}$ and $\mathbf{h}$ ); c, f, i, stem indumentum ( $\mathrm{a}-\mathrm{d}, \mathrm{f}, \mathrm{g}$, i, from holotypes; e, from Coveny 16355; h, from NSW 283785). Scale bar: a, d, $g=5 \mathrm{~cm}$; b, e, $h=6.5 \mathrm{~mm} ; \mathrm{c}, \mathrm{i}=5 \mathrm{~mm} ; \mathrm{f}=2.5 \mathrm{~mm}$. 
from flower to fruit and finally 6-7 $\mathrm{mm}$ long, $2.5-4 \mathrm{~mm}$ broad, with both long and short hairs on the margins near the base and short hairs extending to the apex; outer surface of the lobes almost glabrous. Corolla white tinged with mauve, length 5-6 mm; anterior lobe broad obovate; posterior and lateral lobes almost circular, not folded. Capsule broader than long, 2-3 cm long, 2.5-3.5 mm broad, slightly emarginate, with short fine hairs on the margin; style $4-5 \mathrm{~mm}$ long. Seeds broad ovoid, c. $1.5 \mathrm{~mm}$ long. (Fig. 3, g-i).

Veronica sobolifera has a chromosome number of $2 n=72$ (Briggs \& Ehrendorfer 2006) and can be distinguished from Veronica gracilis R.Br., also octoploid, especially by its taller stems, larger and broader leaves with more serrations, racemes with more numerous flowers, and larger and broader calyx lobes. In V. gracilis stems are mostly 4-25 cm long, leaves 1-4.5 mm broad, entire or with 1-2 teeth on each side, racemes have 2-8 flowers, and calyx lobes are up to $2.5 \mathrm{~mm}$ broad. Veronica sobolifera was referred to as 'Veronica sp. B' in Briggs et al. (1992, p. 580).

The epithet is from the Latin soboles [= suboles] = a sprout or shoot, growing from below, and fero = to bear; referring to the flowering stems arising from extensive rhizomes.

Distribution: Northern Tablelands of New South Wales, in moist eucalypt woodland and grassland, or in swampy sites (Fig. 5).

Conservation status: of restricted range but common in several conserved areas.

Selected specimens examined: New South Wales: North Coast: Gloucester Tops, Briggs, 2 Nov 1968 (NSW 118254); Gloucester Tops, Coveny, 1 Jan 1967 (NSW 98196), 30 Sept 1967 (NSW 101612); Barrington Tops National Park, Coveny, 30 Sept 1967 (NSW 283785); Tubrabucca and Tugalo Top, Barrington Tops, Earp, 1 Dec 1954 (NSW 39755); below Carey's Peak, Barrington Tops, Fraser \& Vickery, 8 Jan 1934 (NSW 6085, SYD); Barrington Tops, Harrison, Jan 1925 (NSW 6084). Northern Tablelands: c. 1 mile [1.7 km] NW of Point Lookout, Williams, Dec 1961 (NE).

\section{Veronica subtilis B.G.Briggs \& Ehrend., sp. nov.}

A Veronica gracilis combinatione characterum sequentium distinguitur: pili caulium brevissimi (c. $0.1 \mathrm{~mm}$ longi); folia intergra, plerumque linearia, 0.8-2 $\mathrm{mm}$ lata; flores parvi, corolla 3.5-5(-8) mm longa; ovarium glabrum.

Holotype: New South Wales: Rocky Plain Creek, 3 miles [c. 5 km] SE of Kiandra, c. 1300 m alt., B.G. Briggs 2531, 9 Feb 1969 (NSW). Isotypes AD, CHR, K, MEL, MO, W.

Herbs with erect flowering stems and long slender rhizomes, surface runners absent. Rhizomes with long internodes and small scale-like leaves. Flowering stems very slender or almost filiform (4-)10-25(-35) mm long; the longest internodes between well-developed leaves (8-)12-40(-60) mm long; stem hairs very short (ca. $0.1 \mathrm{~mm}$ ) papillose, in lateral bands or rarely absent. Leaves entire, mostly linear (those near base of stem or on vegetative shoots sometimes ovate or reduced and scale-like), sessile, narrowed gradually toward apex and base, (7-)11-25(-30) $\mathrm{mm}$ long, (0.5-)0.8-2 $(-2.5) \mathrm{mm}$ broad, the apex acuminate and apiculate, the margins somewhat revolute and thickened, the lateral veins scarcely visible, green or brown when dry, glabrous except for very short antrorse hairs on the upper side at and near the margins. Racemes single or paired at 1-2 nodes of the uppermost part of the stem, clearly overtopping the main axis, (6-)15-55(-80) $\mathrm{mm}$ long with (1-)2-4(-6) flowers; peduncle 
(3-)10-35(-40) mm. Bracts linear, to $6 \mathrm{~mm}$ long. Fruiting pedicels $10-20 \mathrm{~mm}$ long. Calyx lobes broad-linear, acute, in young fruit ca. $4-5 \mathrm{~mm}$ long, $0.6-1 \mathrm{~mm}$ broad; margins and inner surface with very short antrorse papillose hairs. Corolla mauve or pale blue, 3.5-5(-8) $\mathrm{mm}$ long; anterior lobe obovate; posterior and lateral lobes broad obovate to almost circular, not folded. Capsule glabrous, emarginate, slightly broader than long, ca. $2 \mathrm{~mm}$ long, $4.5 \mathrm{~mm}$ broad. (Fig. 3, d-f).

Veronica subtilis is tetraploid $(2 n=36$ : Briggs \& Ehrendorfer 2006) and can be distinguished from the octoploid V. gracilis by the very short hairs on the stem, the entire and generally narrower leaves, very slender peduncles and pedicels, the smaller flowers and glabrous ovaries. In V. gracilis the stem hairs are up to $0.5 \mathrm{~mm}$ long, leaves lanceolate or linear and 1.5-4 mm wide, leaves entire or often with 1-2 serrations on each side, ovaries with dense hairs on margins and apex. Veronica subtilis was referred to as 'Veronica sp. A' in Briggs et al. (1992, p. 581), and as 'Veronica sp. 2' in Briggs and Barker (1999, p. 516). The presence of a linear-leaved species allied to V. gracilis was mentioned by Willis (1973) and Barker (1986).

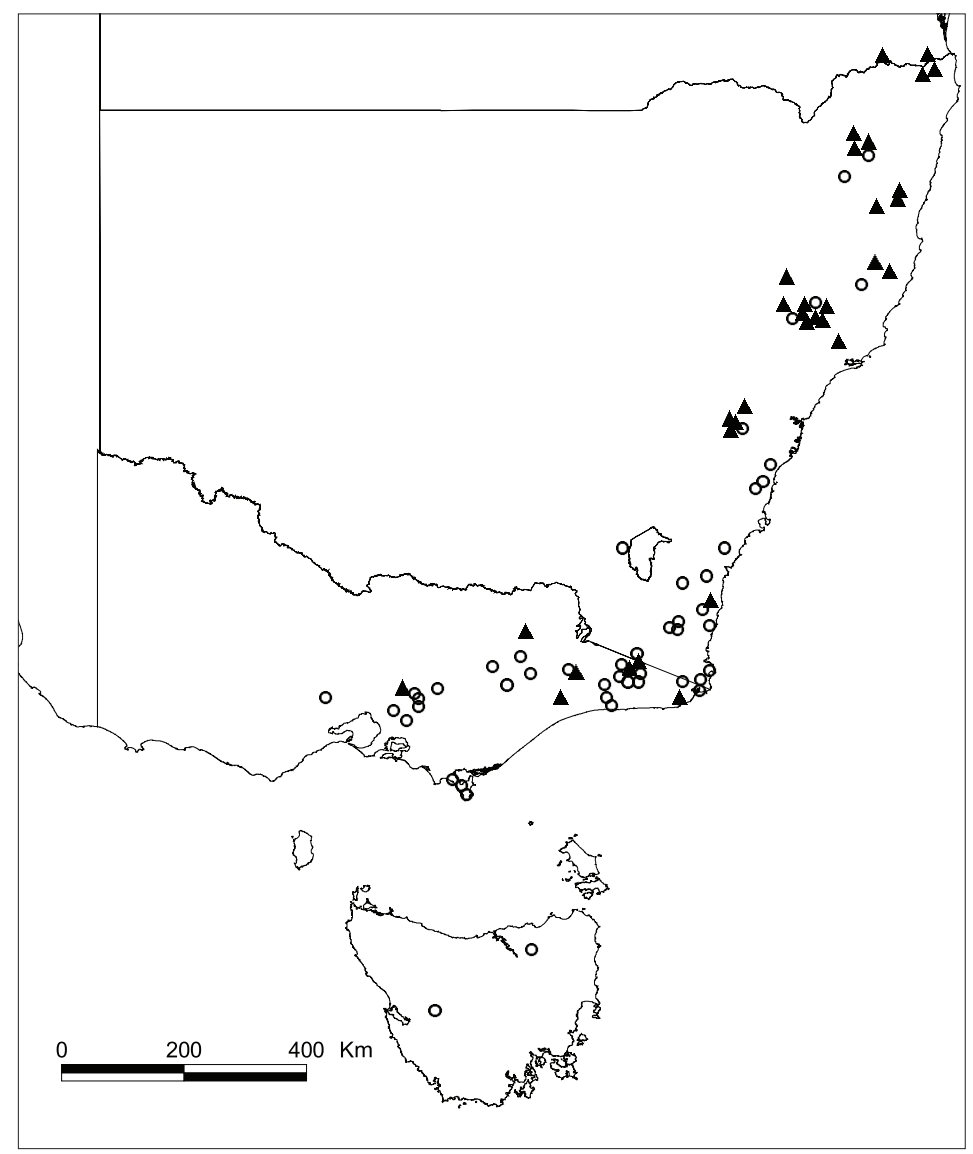

Fig. 4. Distribution of V. grosseserrata $\boldsymbol{\Delta}$ and $V$. notabilis $\circ$ in south-eastern Australia. 
The epithet is from the Latin subtilis = fine, slender or delicate, referring to the stems and leaves.

Distribution: Central and Southern Tablelands of New South Wales, widespread at both high and low altitudes in eastern and south western Victoria and collected from Honans Scrub in the south east of South Australia. In moist sites in swamps, Sphagnum bogs, grassland and grassy forests. Mostly in moister sites than V. gracilis, and on less acidic soils of higher nutrient status (Fig. 5).

Conservation status: widespread and common, occurring in several conserved areas.

Selected specimens examined: New South Wales: Central Tablelands: Brown Mtn, near Littleton, Betche, Feb 1893 (NSW 5962); Tomat Swamp, 8 miles [13 km] SSW of Yerranderie, Briggs 1082 \& Johnson, 29 Nov 1966 (NSW); Bindook Swamp, Colong to Mt Werong, Cambage 3201, 5 Dec 1911 (SYD); edge of Fitzroy Falls Reservoir, Coveny 16355, 8 Jan 1993 (NSW). Southern Tablelands: Sawpit Creek, Mt Kosciusko, Briggs, 31 Jan 1954 (NSW 39758); Upper Cotter Homestead, Burbidge 6368, 24 Feb 1959 (CANB); Upper Cotter, Cambage 3420, 15 Jan 1912 (NSW). Victoria: Genoa, Bauerlen, Feb 1885 (MEL 18017); Surrey R., near Portland, Beauglehole, 26 Nov 1944 (MEL 18013); Gorae West, Beauglehole 8401, Oct 1946 (NSW); Wannon River, E of Mirranatwa Gap, Grampians, Beauglehole 16353, 9 Nov 1967 (NSW); between The Link Road turn-off and Matlock, Johnson, 22 Jan 1967 (NSW 84493); S sources of the Goulburn R. and the N sources of the Yarra R., Mueller (MEL 18011); Ranges of the Macallister R., Mueller, Jan 1863 (MEL 18012); Moroka River Heads on The Big Plain, 2 miles [c. 3 km] NW of Mt Wellington, Muir 3162, 5 Jan 1964 (MEL); Upper Yarra, Walter (BM, NSW 5944); Bullace Glen, Grampians, Warcup, 20 Jan 1961 (AD). South Australia: Honans Scrub, Bates 4835, 20 Jan 1978 (AD).

Veronica brownii Roem. \& Schult., Syst. Veg. 1: 118 (1817), as 'brownei.

$\equiv$ V. arguta R.Br., Prodr. 435 (1810) non Schrad. (1803).

$\equiv$ V. gracilis R.Br. var. arguta (R.Br.) C.Moore \& Betche, Handb. Fl. N.S.W. 341 (1893). Holotype: [New South Wales] Ad ripas fluvii Grose, R. Brown, Nov 1803 (BM!, photo NSW).

Veronica calycina R.Br., Prodr. 435 (1810).

Lectotype (here designated): [Tasmania] In summitati montis primaevi rotundati prope Mount Tabular, R. Brown, Mar 1804 (BM!). The type material of V. calycina at BM includes five of Brown's Australian collections, four from Tasmania and one from Victoria, mounted on two sheets:

A "In summitati montis primaevi rotundati prope Mount Tabular [now Mount Wellington], March 1804”

B "Near outer Cove in Port Dalrymple, Jan. 4, 1804”

C Port Dalrymple

D Prince of Wales, Derwent

E Port Philip [Victoria]

It is evident that Brown's description of this species was based on collection ' $\mathrm{A}$ ' which is therefore here designated as lectotype. Further syntypes and duplicates from Brown's collections are the sheet at K! shown in photo 2639 (CANB), which includes further material of 'E' and probably 'D' and NSW 6233! (which is probably 'D'). Another of Brown's collections, "Summ. Mount., Derwent (K!, photo 2640 CANB p.p., lower specimens on sheet, and also MEL 17955!) was originally labelled "Veronica calycina var. alpina" and is probably not to be regarded as isotype material. 
= Veronica calycina R.Br. var. parviflora Benth. in DC., Prodr. 10: 477 (1846). Holotype: Tasmania, Circular Head, R. Gunn 1218 p.p., 12 Jan 1838 (K!, photo 2643, 2643a CANB, the upper specimens on the sheet). Isotypes NSW 6076!, HO 696A p.p.!

= Veronica gunnii Benth. in DC., Prodr. 10: 477 (1846). इ Veronica calycina var. gunnii (Benth.) Hook.f., Fl. Tasman. 1, 294 (1857). Lectotype (here designated): Tasmania, Cathedral Rocks, Gunn 723, 1836 (K! 'ex Herb. Benth.', photo 2641 CANB). Residual syntype VDL [Van Diemens Land], Gunn (NSW!, K!, CANB photo 2642).

Veronica distans R.Br., Prodr. 435 (1810).

Holotype: [Western Australia] Bald Head, King Georges Sound, R. Brown (Bennett No. 2702), 10 Dec 1801 (BM!, photo NSW).

= Veronica stolonifera Lehm., Sem. Hort. Hamburg (1824, p. 20). $\equiv$ V. calycina R.Br. var. stolonifera (Lehm.) Ostenf., in Dansk. Vidensk. Biol. Medd. 3: 115 (1921). Type (holotype or syntype?): [Western Australia] In arenosis umbrosis prope urbiculam Freemantle, Preiss 2329, 15 Aug [18]39 (LD!).

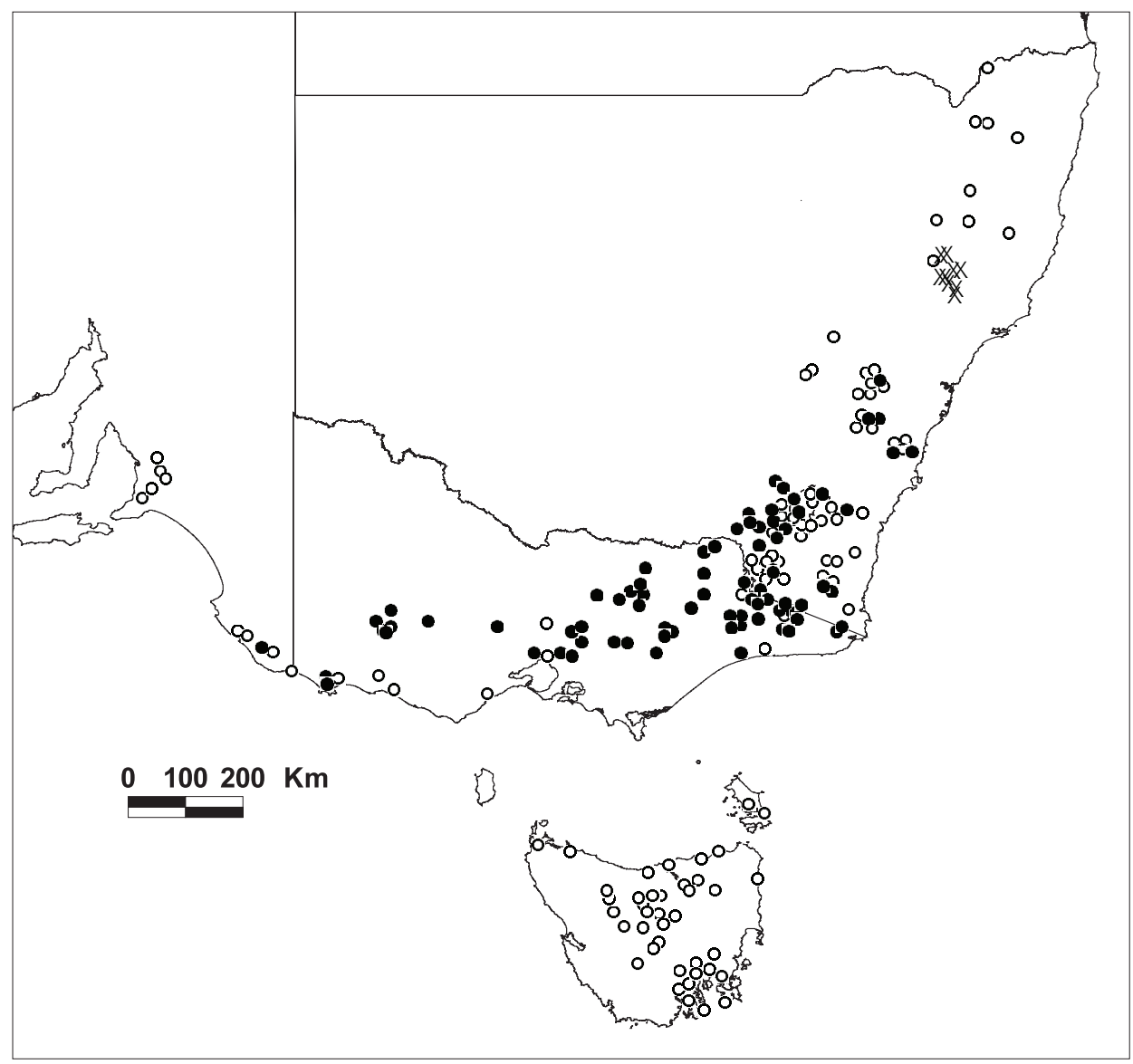

Fig. 5. Distribution of V. sobolifera X, V. subtilis $\bullet$ and V. gracilis $\circ$ in south-eastern Australia 
= Veronica cycnorum Miq. ex Bartl. in Lehm., Pl. Preiss. 1, 342. (1845). Type (holotype or syntype?): [Western Australia] Australia occidentali, Preiss 2414 (LD!).

= Veronica drummondii Benth. in DC., Prodr. 10: 478 (1846). Holotype: [Western Australia] Swan River, Drummond, 1839 (K!, CANB photo 2637).

Veronica gracilis R.Br., Prodr. 435 (1810).

Holotype: [Tasmania] Port Dalrymple, R. Brown (Bennett No. 2704), 1804 (BM!, photo NSW).

Veronica hillebrandii F. Muell., Trans. Philos. Soc. Victoria 1: 49 (1855).

Holotype: [South Australia] Limestone cliffs at Lake Alexandrina, Mueller, Oct 1848 (MEL). The protologue cites 'Barren ridges along the Coorong and on limestone rocks around Lake Alexandrina' but appears to refer to a single gathering.

Veronica notabilis F.Muell. ex Benth., Fl. Austral. 4: 511 (1869).

Lectotype (here designated): [Victoria] Secus rivos umbrosos montium Dandenongrange", F. Mueller, Jan 1853 (MEL 18102!). Probable isotypes (collection details are not given in full on the specimens): K! (photo 2646 CANB); MEL 18099!, 18118!, 18101!, 18103!; Dandenong Ranges, Mueller (LD!). The lectotype bears Mueller's handwritten label and is annotated as having been examined by Bentham. Residual syntypes: Berwick, G.W. Robinson (MEL 18117!, presumably from c. $11 \mathrm{~km}$ ESE of Dandenong, Victoria, rather than from New South Wales as cited by Bentham); Sealer's Cove [Wilson's Promontory, Vic.], F. Mueller, May 1853 (MEL!); St. Patricks R., Tas., R. Gunn 174, 1 Apr 1845 (NSW 5980, 5981!); Clarence River, [Beckler] (MEL 17933!); the last mentioned is a specimen of $V$. grosseserrata.

The collection 'Five Islands District, N.S.W. Cunningham 1819 (BM)' may be that cited by Bentham as from 'Illawarra' (which refers to the same region); it may therefore be a further syntype. It resembles $V$. notabilis but its features show some approach to those of $V$. grosseserrata and it may be hybrid.

Bentham cites 'Grose River, R. Brown' under both V. notabilis and V. arguta R.Br. Only one specimen has been located with these particulars, i.e. the holotype of $V$. brownii Roem. \& Schult. (1817), a nom. nov. for V. arguta R.Br. non. Schrad., and so it must be concluded that Bentham cited the same specimen under both $V$. notabilis and $V$. arguta. In the protologue of $V$. notabilis Bentham states 'This species, which had been determined by A. Cunningham to be the V. arguta of Brown, and was included under that name by myself in the 'Prodromus' [DC., Prodr.] and by Hooker in the 'Tasmanian Flora', proves to be very different from Brown's plant, and apparently as distinct a species as any of the Chamoedrys group in Australia except $V$. nivea.' Also the description in the protologue of $V$. notabilis does not match Brown's specimen, especially in respect of leaf size and indumentum. Clearly Bentham has excluded the Grose River specimen (the type of $V$. brownii) from his concept of $V$. notabilis and so it can be assumed that its citation was simply an error and the name $V$. notabilis is therefore legitimate.

Veronica novae-hollandiae Poir., Encycl. 8: 526 (1808).

Type citation: 'recueillie, dans la Novelle Hollande, per M. Labillardière (v. s. in herb. Desfont.)'. 
Holotype: [Tasmania] labelled 'Veronica Nova hollandiae Poir encycl.' and 'Herb Webbianum ex Herb. Desfontaines' (FI!, photo NSW). Probable isotype (K!, photo 2638, 2638a CANB).

= V. calycina R.Br. var.? longifolia Benth., Fl. Austral. 4: 510 (1869). Holotype: Tasmania, Hampshire Hills, Gunn 174/1837, Feb 1887 (K!).

Veronica parnkalliana J.M.Black, Fl. S. Austral. 3: 512 (December 1926); also in Trans. \& Proc. Roy. Soc. South Austral. 50: 286 (23 December 1926).

Holotype: Near Port Lincoln, H.H.D. Griffith, 10 Oct 1909 (AD 96645025!, photo NSW; iso $\mathrm{K})$.

Veronica plebeia R.Br., Prodr. 435. 1810.

Holotype: [New South Wales] in humidis prope Sydney, R. Brown, May 1802 (BM!). The collection from Williams and Hunter's Rivers, R. Brown, Nov 1804 (BM!, K!, CANB photo 2644) was used for a description of an unpublished variety and is not regarded as a syntype.

$=V$. deltoidea Spreng., Syst. Veg. 4 (2) 17. 1827. Type (holotype or syntype?): [New South Wales] Sieber, Pl. Nov. Holl. 483 (K!, CANB photo 2645 p.p.).

=V. vitifolia Sm. ex Walp., Repert. Bot. Syst. 3: 367. 1844. Type (syntype?): Port Jackson, New South Wales, collector not stated, (LIV! ex herb. [J.E.] Smith).

=V. elongata Benth. in DC., Prodr. 10: 478. 1846. Typification: Bentham cites "in New Zeelandia, (A. Cunningham! Sinclair! Edgerley!)". The sheet in K (!) bears a label "No. 382, Bay of Islands, New Zealand 1838" and the name "Allan Cunningham" is written on the sheet near this label; a separate label on the sheet reads "B. of Islds. Dr Sinclair". It is not clear how much of the material should be attributed to each of these collectors.

\section{Veronica sect. Hebe: Chionohebe clade}

From this small clade, centred on New Zealand, only the typification of $V$. densifolia is considered here.

Veronica densifolia (F.Muell.) F.Muell., Fragm. 2: 137 (1861),

三 Paederota densifolia F.Muell., Trans. Philos. Soc. Victoria 1: 107 (1855).

三 Chionohebe densifolia (F.Muell.) B.G.Briggs \& Ehrend., Contr. Herb. Austral. 25: 2 (1976).

=Leonohebe densifolia (F.Muell.) Heads, Bot. Soc. Otago Newslett. 5: 4 (1987).

三 Hebejeebie densifolia (F.Muell.) Heads, Bot. Soc. Otago Newslett. 36: 11 (2003).

Type citation: On the highest rocky summits of the Munyang Mountains (6-6500 feet) [F. Mueller].

Lectotype (here designated): Munyang Mountains, Mount Coskiusko [=Kosciusko], 6000-6500 ft., Mueller, Jan 1855 (MEL 21502!). Residual syntypes: Munyang Mountains, $6000 \mathrm{ft}$, [Mueller] (MEL 21503!); Munyang Mtns 6000', F v Mueller (K!, two sheets: one from Hooker herbarium, the other from Linnean Society); Mount Coskiusko 6000', F v Mueller (K!). Possible syntype: Mount Coskiusko, [Mueller?] (MEL 21504!). 


\section{Acknowledgments}

We thank Lesley Elkan for the illustrations; Bob Makinson, Barbara Wiecek and Louisa Murray for technical assistance; Peter Wilson, John McNeill, Gillian Perry and Nigel Walsh for assistance in matters of typification or nomenclature; Peter Wilson for help with the Latin diagnoses; Linn-Linn Lee, Lucy Nairn and Gary Chapple for assistance in preparing the maps; and Dirk Albach for valuable comment on the manuscript.

\section{References}

Albach DC \& Chase MW (2001) Paraphyly of Veronica (Veroniceae; Scrophulariaceae): evidence from the internal transcribed spacer (ITS) sequences of nuclear ribosomal DNA. Journal of Plant Research 114: 9-18.

Albach DC, Martinez-Ortega MM, Delgado L, Weiss-Schneeweiss H, Özgökce F \& Fischer MA (submitted) Chromosome numbers in Veroniceae: Review and several new counts. Annals of the Missouri Botanical Garden.

Albach DC, Martínez-Ortega MM, Fischer MA \& Chase MW (2004) A new classification of the tribe Veroniceae - problems and a possible solution. Taxon 53: 429-52.

Albach DC, Meudt HM \& Oxelman B (2005) Piecing together the "new" Plantaginaceae. American Journal of Botany 92: 297-315.

Barker WR (1986) Scrophulariaceae. Pp. 1275-1313 in Jessop JP \& Toelken HR (eds) Flora of South Australia, vol. 3, 4th edition. (South Australian Government Printer: Adelaide)

Bayly MJ \& Kellow AV (2006) An illustrated guide to New Zealand Hebes. (Te Papa Press: Wellington)

Borgmann E (1964) Anteil der Polyploiden in der Flora des Bismarckgerbirges von Ostneuguinea. Zeitschrift für Botanik 52: 118-172.

Briggs BG \& Barker WR (1999) Veronica. Pp. 509-516 in Walsh NG \& Entwisle TJ (eds) Flora of Victoria, vol. 4. (Inkata Press, Melbourne)

Briggs BG \& Ehrendorfer F (1992) A revision of the Australian species of Parahebe and Derwentia (Scrophulariaceae). Telopea 5: 241-87.

Briggs BG \& Ehrendorfer F (2006) Chromosome numbers of Australian and New Guinean species of Veronica (Plantaginaceae). Telopea 11(3): 294-298.

Briggs BG, Wiecek B \& Whalen AJ (1992) Veronica. Pp. 578-582 in Harden GJ (ed.) Flora of New South Wales, vol. 3. (New South Wales University Press, Kensington)

Brummitt RK (2006). Am I a bony fish? Taxon 55: 268-269.

Coates F, Kirkpatrick JB \& Minchin D (1999) Towards an explanation of the causes of the rarity of two Tasmanian Spyridium species. Australian Journal of Ecology 24: 11-17.

Garnock-Jones PJ, Albach D \& Briggs BG (submitted) Botanical names in Veronica sect. Derwentia, sect. Detzneria and sect. Hebe (Plantaginaceae). Taxon.

Heads MJ (1992) Taxonomic notes on the Hebe complex (Scrophulariaceae) in the New Zealand mountains. Candollea 47: 583-595.

Kirkpatrick JB \& Brown MJ (1984a) The palaeogeographic significance of local endemism in Tasmanian higher plants. Search 15: 112-113.

Kirkpatrick JB \& Brown MJ (1984b) A numerical analysis of Tasmanian higher plant endemism. Botanical Journal of the Linnean Society 88: 165-183.

Olmstead RG, dePamphilis CW, Wolfe AD, Young ND, Elisons WJ \& Reeves PA (2001) Disintegration of the Scrophulariaceae. American Journal of Botany 88: 348-361.

Olmstead RG \& Reeves PA (1995) Evidence for the polyphyly of the Scrophulariaceae based on chloroplast $r b c \mathrm{~L}$ and $n d h \mathrm{~F}$ sequences. Annals of the Missouri Botanical Garden 82: 176-193.

Römpp H (1928) Die Verwandtschaftsverhältnisse in der Gattung Veronica. Repertorium species novarum regni vegetabilis. Beihefte 50: $1-172$.

Sykes WR (1988) Scrophulariaceae. Pp. 1175-1214 in Webb CJ, Sykes WR, Garnock-Jones PJ Flora of New Zealand, vol. 4. (Botany Division, D.S.I.R.: Christchurch) 
Wagstaff SJ \& Garnock-Jones PJ (1998) Evolution and biogeography of the Hebe complex (Scrophulariaceae) inferred from ITS sequences. New Zealand Journal of Botany 36: 425-37. Wagstaff SJ \& Garnock-Jones PJ (2000) Patterns of diversification in Chionohebe and Parahebe (Scrophulariaceae) inferred from ITS sequences. New Zealand Journal of Botany 38: 389407.

Wagstaff SJ, Bayly MJ, Garnock-Jones PJ \& Albach DC (2002) Classification, origin, and diversification of the New Zealand hebes (Scrophulariaceae). Annals of the Missouri Botanical Garden 89: 38-63.

Willis JH (1973) A handbook to plants in Victoria, vol.2. (Melbourne University Press: Carlton)

Manuscript received 7 March 2006, accepted 6 July 2006 